\title{
カラーシート検査装置の開発及び導入事例*
}

\author{
オムロン株式会社 ビジョンシステム事業部技術部 松 井 秀 人
}

\section{We Perfected the New Color Inspection System at Last}

\section{Hideto Matsui}

Technology Department, Vision Systems Business DIV. Omron Corporation

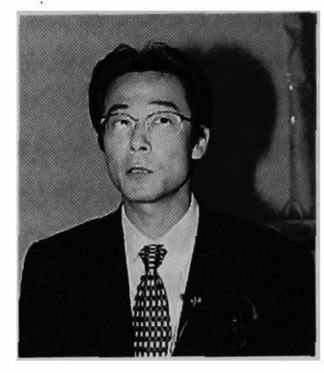

New Inspection System (ASP-P 3500-M) adoption 3 CCD Color line sensor. Distinction is pattern matching. This System is detection a small defect and a light defect. Conception a development easy operation and high capability and detection stability. System consists of Sensor unit, Indicate unit, Conduct unit and Control unit. Indicate unit is Dos/V PC (Windows NT). Conduct unit is SBC (OS-9).

Control unit is PLC. High technology used all units. We are confident this System of a highly efficient detection.

分類： $V_{4}$ 紙バルプ工程計器およびセンサ, $\mathrm{N}_{4}$ 叙工機検查装置

\section{1.はじめに}

カラーシート検查装置は既に 2 年前, 旧印刷機用検 查装置 DOPRIME をべースに, 無地シート向けに改 良し納入している。この装置は, $1 \mathrm{~K}$ 三板式カラーラ インセンサーが各面 1 台しか接続できず, 用途が限ら れた。

しかし，新型印刷機用検査装置の完成により，旧型 では実現できなかった様々な機能を向上し， 21 世紀 に向けたカラーシート検查装置が実現できると確信し た。9 98 年の計装ショーにデモ出展後, 既に 2 台の装 置が稼動している。機能上まだまだ不備はあるが，こ れまでの検査装置にない確実な検出が実現できている。

以下に, 今回開発したカラーシート検査装置につい て, 開発の経䋨, 装置構成, 特徵, 稼動状況を説明す る。

•平成 11 年度年次大会講演（講演 No. C 17）

\section{2. 開発経緯と経過}

\section{1 検査能力の大幅な向上}

旧型の装置では, $1 \mathrm{~K}$ カラーカメラが表裏各面 1 台 しか接続できず，分解能を上げることができなかった。 新型では, $2 \mathrm{~K}$ カラーカメラを各面 2 台まで接続可能 となり, 分解能を 4 倍に向上できた。

さらに, 淡久陥，スジ欠宿の検出アルコリズムが追 加され, 秖幅 $2,000 \mathrm{~mm}$ 程度なら十分要求検查能力を 満足できると確信した。しかし，この装置の開発ター ゲットは印刷物の検查であり，この装置をそのまま無 地シート向け検查装置として商品化するには不備も多 く, 以下に記述する問題点を解決し, 商品化に向けて 開発をスタートした。

\section{2 蛇行補正機能の充実}

カラーシート検査装置の判別方式は, パターンマッ チングという方式であり，被検査物の蛇行は誤欠陥と なり致命的である。この蛇行を補正し，正確に久陥判 別するために蛇行補正をおこなっている。印刷物を検 
查する場合は印刷された柄により，特徽抽出を行い検 查画のズレを修正してマッチングを行う。従って, 印 刷物の場合は, 検查領域の中にこの特徽がある。無地 シートの場合, 特徵は紙端である。従って, 特徵は検 查領域の外にあり, 検査領域外に特徴抽出エリアを設 ける必要があった。さらに, オペレータに操作上の負 担をかけることのないよう, 簡単な操作でこれらのエ リアを設定できるようにする必要があった。

検查領域については領域設定操作釦により, 設定紙 幅付近の画像を CRT 上に表示し, 对話方式で設定で きるようにした。これに対し, 蛇行補正抽出エリアは 検査領域をもとに，自動的に拡大したエリアを設定す るようにした。この機能により，無地シートにおいて もマッチングによる欠宿判別が可能となった。

\section{3 高速処理の実現}

カメラからの画像信号が多くなると同時に, 処理時 間も比例してかかってしまう。画像量が 4 倍になった ことで, 処理速度を大幅に向上する必要性があった。 これまでソフト処理で行なっていた，画像アスペクト 変換（分解能に合わせ縦, 横の比率を可変し, 本来の 形状に戻す機能）等旧装置で確立できた機能をハード 化することにより画像処理速度を大幅に向上した。さ らに, 高速 SBC の採用と, 機能分散により各 CPUの 処理時間を最適化することで目標の 4 倍以上の高速処 理を実現した。

画像の保存では，旧装置では $3 \mathrm{M}$ の画像を表示後， 保存するまでに約 20 秒を要していたが, パソコンの 高速化と, OSにWINDOWS NT を探用したことで 6 $\mathrm{M}$ の画像を約 6 秒で表示し保存することが可能とな った。

\section{4 デー夕処理}

開発当初は，PLCによりデー夕処理を行なおうと 取り組んだ。近年のめまぐるしい技術革新により， PLCでもデータ処理は可能であろうと考えていたか らである。実際, 各ユニットのソフト開発が進むにつ れ, 中型 PLCではスペックオーバーであることが判 明した。

ところが，PLCを上位機種に代えることもできな かったのである。PLC とパソコン間はCLK リンク, $\mathrm{PLC}$ と SBC 間は SLK リンク, パンコンと SBC 間は SCSIによりトライアングルでデータ通信を行なって いる。このうち, 上位機種にはまた CLK ユニットが なかったのである。最終的に情報のロギングを SBC に, 動作タイミンクをPLCに, 最終データ編集と保 存をパソコンに行なわせることで简単なデータ処理を 実現した。
これらのデータは，沉用性のある形式で保存するこ とにより, 装置以外のパソコンでも開くことが可能で ある。ネットワークで別のパソコンと接続した場合, 画像はビットマップデータを開くソフトで展開が可能 であり，画像以外のデータはテキストデータを開くソ フトで展開できる。今後，様々な機器との接続を想定 し、データのやり取りを可能とした。

\section{5 運用ソフトウェア}

カラーシート検查装置の開発にあたって一番苦労し たのは，運用に関するソフトウェアである。極力オぺ レータに負荷をかけないよう設定は最小限にとどめ, かつ必要なパラメータはなんらかの形で入力しなけれ ばならない。

パラメータの大半は, 検査開始前に設定する必要が あり，検查中は変更できない。これは，パラメータに 基づき画像処理していくため, パラメータの変更は, 画像処理を変更することであり, 検査中の変更はパ夕 ーンマッチングする画像を替えることになる。従って, 一旦検査に入るとパラメータは変更できない。

印刷機の場合，まず色合わせという作業があり，機 械を稼動しながらパラメータを修正できるタイミンダ がある。しかし，抄紙機ではこのタイミングはない。 この対応として, パラメータをテーフル化し, 生産す る紙の情報を選択（紙の色，地合いの状態等）すれば, パラメータはテーブルより自動設定されるようにした。

納入後も運用上様々な問題があり, 王子製秤株式会 社大分工場の御指導のもと使い易い装置となるよう改 善することで, 完全とはいえないが, 抄紙機, 加工機 でも十分使える装置が完成した。

\section{3. 装置構成}

図1に示す。

\section{4. 装置の特徵}

\section{1 入 力 部}

1） ラインスピードに関係なく一定の分解能（ライ ンに同期）に保つ。

2） 久宿信号を強調するのではなく，より忠実に信 号を取り出す。

3）三板式カラーラインセンサー，防應専用レンズ, 三波長専用蛍光等により, CCD 感度（RGB）を最適 化。

4）カメラ内で光信号に変換するため, 長距離伝送 でもノイスに強く，信号の減衰をを起こさない。

5）デジタルシェーディング機能で, レンズ収差, 光源バランス, CCD ビット特性を補正。表裹各面で, 


松井秀会

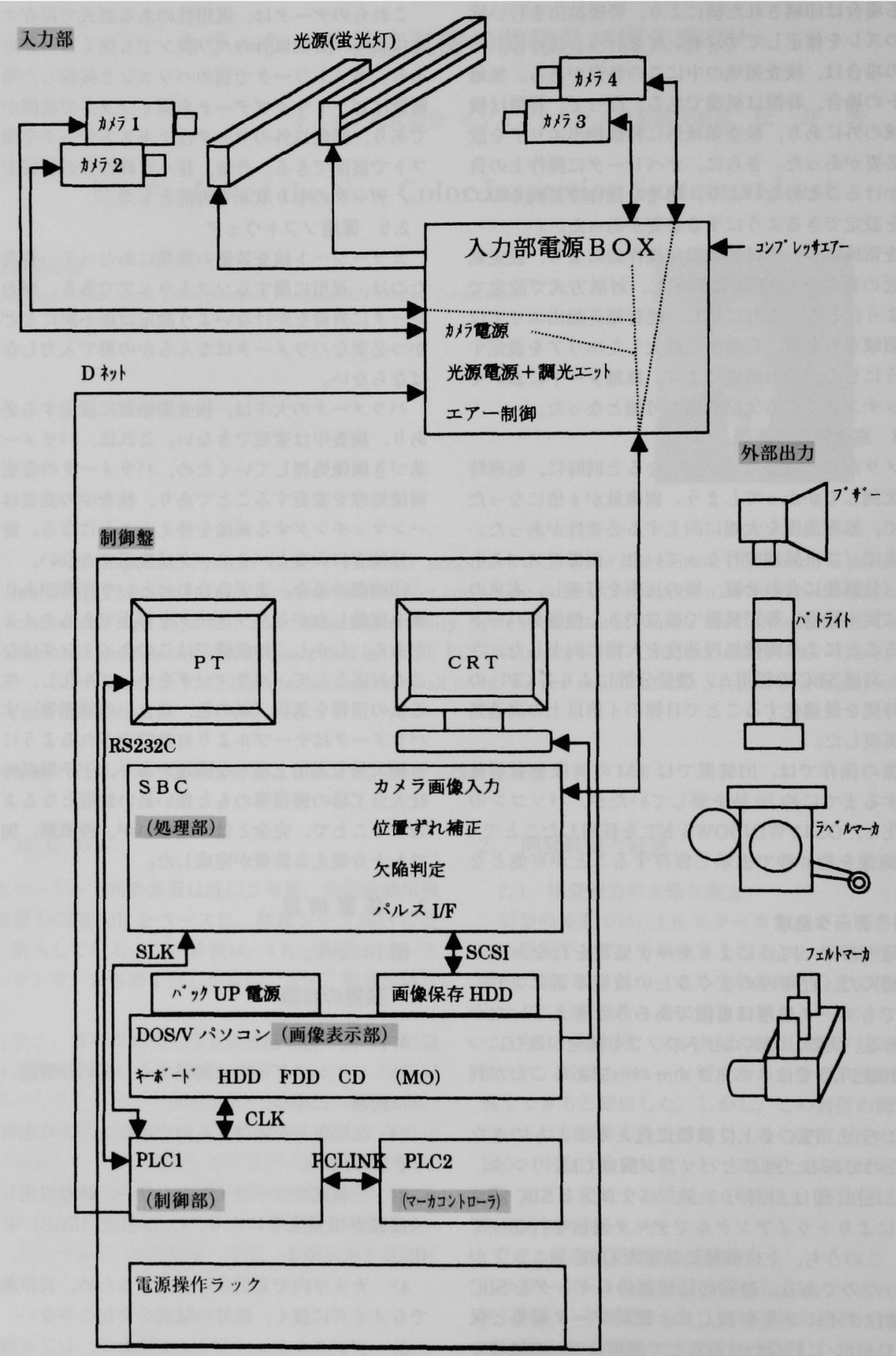

図 1 システム構成 


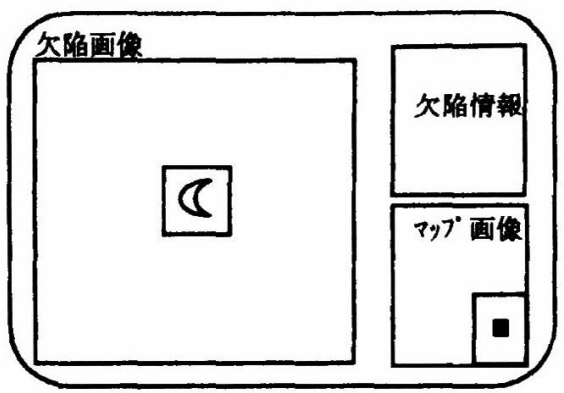

図 2 CRT 表示イメージ図

最も感度の良いビットを基準に全てのビットデータを 補正。カメラ間の特性バラッキも同時に補正する。

6）蛍光等使用時間に合わせ蛍光等出力を補正し, 約 6 ケ月間に渡り安定した光量を保つ。

7）カメラは通信機能を持ち, ゲイン調整は CRT で画像を見ながら，制御部から操作可能。

8）専用レンズは完全防塵構造で紙紛に強い。さら に絞り,ピントはロック式で調整後の経年変化が起き ない。

\section{2 画像表示部（図 2)}

1) 取り込み釷入力時は, カメラ間画像を合成し, 全体画像を表示可能（拡大釦で拡大表示も可能）。

2) 久陥画像はカメラ全体マップ画像と, 欠陥部分 拡大画像，欠陥情報を同時に表示することで，位置の 把握，どんな欠陥か瞬時に把握できる。また，欠陥に は欠宿種別に色を変えて染表示も可能であり，さらに 欠陥部分を画面に中央に表示することで見やすい。

3） OSにWINDOUS NTを採用し，24時間連続 運転でも安心できる。

4) 画像保存は外付けHDD とし，アクセスの多い (壊れやすい) HDDを内缄 HDD と切り離すことで, アプリケーションを保護している。

5）画像プロファイル，ダンブ表示機能を持ち，久
陷画像の解析可能。

プロファイル：欠陥部分にカーソルを当てると, 縦 または，横方向に，RGG 分布データをグラフ表示。

ダンプ：欠陥部分にダンプ枠を当てると，16×16 画素のウィンドで RGB 階調デー夕を数字で表示。

6） 欠陥表示は自動アスペクト変換後表示するため, 分解能 (縦，横）にかかわらずもとの形状で表示可能。

4.3 処 理 部

1）設定ライン数を 1 面画像とし，この画像単位に 欠陥判別を行なう。これまでのライン処理と比較して エリア処理では欠陥を 3 次元でとらえられるため，精 度の离い判定結果がえられる。また, 久陥判別はパ夕 ーンマッチング方式で行ない，検査開始時に良品を記 憶し，検查画像と比較することで欠陷を抽出する。

2) 久陥種別は, スポット久陥 3 種類, スジ久陷, 淡欠陥の計 5 種類の欠陷判別に分類される。さらにス ポット欠陷では，これまでの検査装置のような優先処 理はない。スポット久陥の判定には, 濃度差, 画素数 の雨方を越えたものが欠陥として処理する。

3） 欠宿判別は $16 \times 16$ 画素のウィンド単位で行な う。また，欠俩がウィンドにまたがった場合，画素数 （大きさ）が正確に判別できないため，判定ウィンド を縦，横方向にそれぞれ半ウィンドずらし，判定ウィ ンドをラップさせることで，正確な欠陥判別が行なえ る。

4）指定幅内を正確に検査できる。検查幅設定で指 定されたエリアを紙端を基準に，常に検査できる。蛇 行発生時も, 検査画像から蛇行量を計算し, 修正する。 従って，生産として保証する紙幅を検査領域として設 定しておけば，検査結果は製品品質の目安となる。

\section{4 制 御 部}

当社ではじめて MMIにPT（タッチパネル）を採 用し，簡単操作で使い易いMMI を実現した。

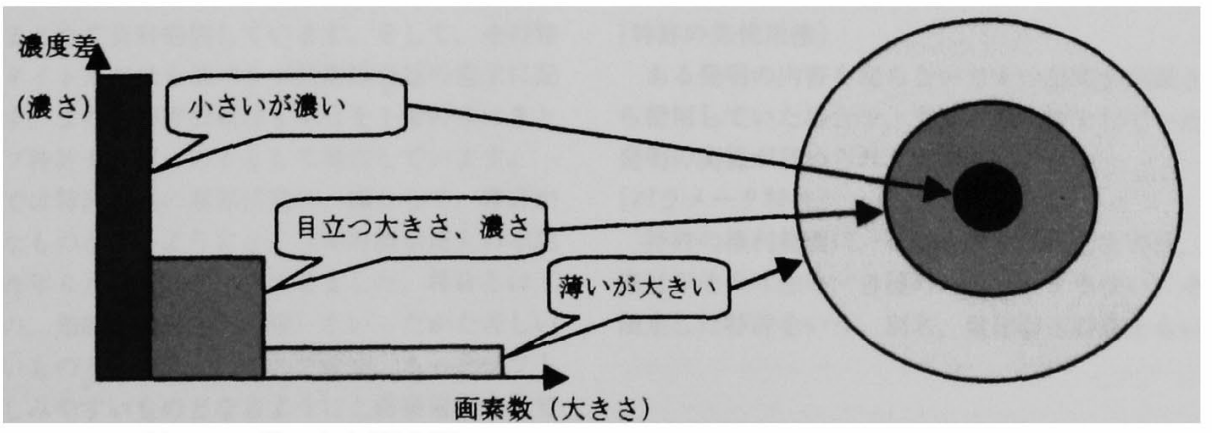

図 3 スポット久陥分類
図 4 欠陷イメージ 


\section{5. 道入事 例}

\section{1 板紙検查装置（抄紙機）}

\section{1 .1 仕様}

1）被検查物：多色板紙

2）分 解 能:幅 $0.25 \mathrm{~mm}$, 流れ $0.486 \mathrm{~mm}$

3）ライン速度: $200 \mathrm{~m} / \mathrm{min}$

4) 処理単位: $486 \mathrm{~mm}(0.486 \mathrm{~mm} \times 1,000 \mathrm{P})$

5.1 .2 道入, 運用状況

1）表面のみのリプレースという形で納入し, 裏面 はこれまでの検査装置を残した。操作が二重にならな いよう，稟面検査装置と信号を接続し，極力これまで の操作方法で運用できるようにした。

2） ラー画像での欠陥表示は，これまでのモノクロ 録画装置に比べ, 欠陥自身が鮮明に写し出され，抄紙 機の状態もわかる。

3）設定しだいで微小欠陥はもとより，淡い欠陥の 検出も可能である。板紙の場合「水垢」が出てしまう が,これまでの検査装置では検出が不安定であった。 カラー検査では, $\mathrm{R}$ (赤) が大きく変化し十分検出で きる。

4）検査ポイントでのシートのバタッキ（駆動側の 波）が大きくなった場合, 誤欠陥となる場合がある。 欠陷画像だけ見ると良くわからないが, マップ画像を 見ると, 紙の浪打がはっきりわかる。これまでの検查 装置と比較した場合，バタッキには弱いものの逆に， 変化は変化として正確につかむという特徵でもある。

\section{2 色塗工紙検査装置 (塗工機)}

\subsection{1 仕様}

1）被検查物：多色塗工紙
2) 分 解 能: 幅 $0.38 \mathrm{~mm}$, 流れ $0.3 \mathrm{~mm}$

3）ライン速度 : $120 \mathrm{~m} / \mathrm{min}$

4) 処理単位: $300 \mathrm{~mm}(0.3 \mathrm{~mm} \times 1,000 \mathrm{P})$

\section{2 .2 道入, 運用状況}

1）塗工紙ということで，反射，正反射の併用方式 で設置。塗工状態（原反種）設定により, 光量バラン スを変更する。光沢度の高いものは, 正反射の出力を 上げ, 光沢の変化も検査する。正反射もあるため, 検 查はロール上で行なっており，バタツキもないため， シビアな検查も可能である。

2）色数が多いため, カラーでの検査はその性能を 十分発揮している。塗工ムラなどの同色欠陥は，これ までのモノク口検查方式では検出できなかった欠陥で ある。

3）塗工機の場合，運用自体が印刷機と似ており， 比較的操作上の問題が少なかった。塗工機に場合, 塗 工開始後巻取りまでシートが流れてくるまでに時間が あり，パラメータを設定できるタイミングがある。設 定操作を極力少なくしたことで，オペレータに大きな 負荷をかけることなく運用されている。

\section{6. 最後に}

まだまだ，商品の完成度としては低く，多種，多用 に展開はできませんが, 今後, 多色紙 (抄紙機), 加 工機等にも展開が決まっており，さらに使いやすく， 検査精度を向上します。これまで培ってきたシート検 査装置のノウハウを更に取り入れ，新しい概念と融合 しながら，21 世紀に向けた検查装置を目指して完成 度を上げてまいります。 
知財散步道 (7)

\section{もっと身近な特許について}

日本板紙株式会社研究開発部 奥村礼二

通産省・特許庁は特許権を売り買いする本格的な流通市 場づくりに力を入れている。現在，国内には利用されてい ない特許，すなわち休眠特許が 40 万件もあると推定され ており，これを企業の製品開発につなげ，日本経済全体の 競争力を高めようとする狙いがある。特許市場は数少ない 手つかずのマーケットとして，特許自体が商売になると考 えられている。従来, 特許といえば，自社が開発した技術 について他社の模做を防ぐといった権利保護の意識が強か った。未利用のままの休眠特許を他人が使えば新しい価値 を生み，利益にもつながると考えている。この政策の背景 には, 米国企業の存在があり，1990 年ごろから IBMのよ うに特許櫵なと知的財産部門を強化し，ライセンス収入を 利益の柱とする企業が目立っている。しかし，国内で特許 を仲介する業者は，米国に比べるとまだまだ少なく，市場 の芽といった段階にある。

捋来, 特許の流通市場など知的財産権のサービスを充実 させるには，并理士の增貝が不可欠である。現在，国内で の并理士の有資格者は，4160人で米国の約 2 万人に比べ てかなり少ない。并理士は特許の登録を主な仕事としてい るが、今後は仲介業務や紛争処理の面での活躍が期待され ている。

国内の企亲でも特許収入を重視する動きが出始めており， 日立製作所の 98 年度の特許によるライセンス契約での収 入は 494 傹円にも達し, 年間売上高の約 $1 \%$ を占めてい る。

ところで，紙パルブ技術協会の特許委貝会ではどのよう な事をしているのかと思われている方が多いと思います。 ここでその仕事の一部を紹介させていただきます。まずは， 秖パルブ関連の特許公報, 公開特許公報, 実用新案公報だ けを取り出し，内容別に分類して，月 2 回のペースで特許 抄録の形にまとめて資料提供しています。そして，その特 許公報他のタイトルだけを紙パルブ技術協会誌の巻末に記 載しています。また，特許公報は 1 年分を 1 冊の本にまと め, 紙パルブ特許タイジェストとして発刊しています。

本委員会では特許関係の業界活動の一環として, 特許が もっと身近なものとなるようにと，「知財散歩道」の本誌 への記载を昨年 6 月からスタートさせました。特許とは工 業所有権だの, 知的財産権（所有権）といったかた苦しい もの, 難しいものとして扱われがちですが,もっとンフト タッチで親しみやすいものとなるようにと敬蒙活動をして いきたいと思います。
今年の年次大会（仙台市）では, 特許庁が昨年 3 月に創 設しました特許電子図青館（IPDL）について紹介をする とともに，展示場にブースを設けて公報類の閲覧を始め, 経過情報の検索などができる展示実演を計画しています。 年次大会に参加の方は，ぜひ拉立ち寄り下さい。

以下の紙面を利用して耳慣れない特許関連の専門用語の 解説をします。

[国際特許分類 (IPC)]

特許文献に記載されている発明の分類の体系。世界各国 が共通の特許分類を使用することにより，特許文献の整理 や検索，または審查の便を図るために作られ，71 年のス トラスプール協定により規定された。

[サブマリン特許]

出願後, 相当の年月が経ってから突然権利化される特許 をいう。潜水艦のように突然浮上するところから名付けら れた。とくに米国では先発明主義で公開制度が無いことと， 特許期間（シーリング）が特許発効日から 17 年であった ため，突然登場することが多かった。古い技術ですでに世 の中の寒質的な標华になって，一般化して常識となった技 術に長い期間にわたり保護し独占できる権利が付与される ため, しばしば問題を投げかけていた。しかし, 95 年以降 は出願日から 20 年というシーリンクがかけられるように なり，このような問題はなくなっている。

[情報提供]

出願公開された発明の内容に，新規性や進歩性がないと いう証拠の情報を特許庁に提出すること。その結果のフィ ードパックを受けることもできる。

[先願主義と先発明主義]

同一の発明が行われたとき，一日でも先に出願されたほ うに特許権が付与されるのが先願主義で, 日本をはじめ世 界の多くの国がこの制度を探用している。これに対して米 国が探用している先発明主義は, 出願の先後にかかわらず 先に発明した者に特許権が付与されることをいう。

[早期審査]

特許出願の藉査は原則として出願順に着手される。しか し，現在その発明を実施しているとか， 2 年以内に実施が 予定されている場合には，優先して䧽查を受けることがで きる。外国に出願したものであれば，早期賽査の対象とな る。

[特許の先使用権］

ある発明の内容を知らないでその発明が出願される前か ら使用していた場合や，実施する染備をしていた場合に， 発明の実施が認められる実施権のこと。 [パラメータ特許］

特許の権利筂囲に，化学物犋や触媒の含有量，ある種の 素材やその寸法等, 各種のパラメー夕を使い，その能囲を 限定した特許をいう。別名, 数值限定特許ともいわれる。 


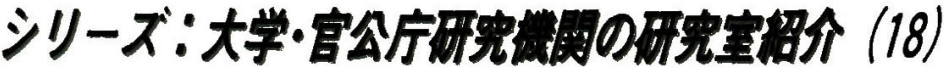

Introduction of Research Laboratories(18)

\section{高知大学農学部森林科学科 森林資源利用学講座 木材化学研究室}

Laboratory of Wood Chemistry, Division of Forest Products, Department of Forest Science, Faculty of Agriculture, KOCHI UNIVERSITY

沿革

高知大学は昨年, 開学 50 周年を迎え, 幾つかの記念事 業をとり行いました。昭和 47 年に林産物の化学的利用に 関する研究・教育を行なうために農学部林学科に木材化学 講座が新設され，現在の木材化学研究室に続いています。 平成 5 年には農学部改組が行なわれ，林学科は森林科学科 に名称を変更するとともに，森林資源学講座と森林資源利 用学講座の 2 大講座制をとることになりました。それと同 時に，森林科学科はそれまでの林業・林産業の観点からだ けでなく，森林のもつ環境保全の役割を重視し，広い視野 に立って森林を育成・管理し，持続的に利用するための教 育研究、森林資源の高度・循環利用に関する教育研究を行 い,これらの活動を通じて各分野で活躍できる人材の養成 を目指しています。

スタッフ・大学院生

教官として, 鮫島一彦 (教授) と大谷慶人（助教授）の 2 名で研究指導と教育にあたっています。昨年 4 月からは, 王家駅博士が会社からの派遺研究貝として, 程舟博士が文 部省のポストドクター研究員として研究にあたっています。 全体として大学院博士課程 1 名 (今年 3 月修了予定), 修 士課程 6 名, 学部学生 4 名が在籍しています。当研究室は 外国人研究員・留学生 5 名を抱え，国際色豊かです。 研究内容とテーマの紹介

森林資源の保全と化学的高度利用を目指して, 現在 3 つの 大きなテーマに取り組んでいます。

(1) ケナフの総合的利用法の開発

ケナフは一年生の植物で綫維材料として注目を集めてい ますが, 当研究室ではケナフの特長を活かし, その価值を 高めるための総合的な研究を行なっています。まず,ヶナ フ品種の同定, 栽培技術・収穫方法の改良などを通して紙 パルプ原料に最適な生産法を検討しています。更に，樴維 劣化および環境負荷の少ない常圧・加圧パルプ化の条件を 探ることにより，手渑き和紙などの特殊紙および不織布な どに適する䋞維調製技術の検討も行っています。それ以外 では，パルプとして使用しない芯部についてはキノコ培地 および炭化材料としての利用研究や, ケナフ自身の抜群の

分類 : $Z_{s}$ 学校 $\cdot$ 研究機関・団体紹介
成長力・養分吸収力を利用した排水処理など織維原料に限 らない幅広い用途の開拓を進めています。

(2) バクテリアセルロース製造技術の改良

酢酸菌が生産する七ルロースは高純度で種々の用途が期 待されていますが, 生産性が低く, 使用培地が高価なこと から実際の工業的用途は限られています。当研究室では低 価格の培地から如何に高収量のセルロースを得るかを検討 しています。既に，亜硫酸パルプ蒸解廃液成分であるリク ニンスルホン酸塩を培地に添加すると著しくセルロース収 量が增加することを明らかにしており，その増収メカニズ ムを解明することにより更なる収率の向上および安価な製 造法の開発に向けて研究しています。

(3) 木材保存に関する研究

高知県は温暖な地域であるためにシロアリ，木材腐朽菌 の活動が活発で，それらによる木造建築物の被害が大きな 問題となっています。現在, シロアリに関してはイエシロ アリだけでなく，従来不明点の多かったヤマトシロアリの 生態および防除に関する研究を進めています。他方，これ らの生物劣化に対する耐久性は木材の抽出成分に大きく依 存するので，木材抽出成分と耐久性との関連を調べると共 に, 抽出成分の積極的利用法も検討しています。

最近の主な学会発表・学会誌報告

(1) Z. Cheng. Y. Ohtani, K. Sameshima, and Z. Mei : Selection of Kenaf (Hibiscus cannabinus L.). Varieties for papermaking on arid hillside land in China.

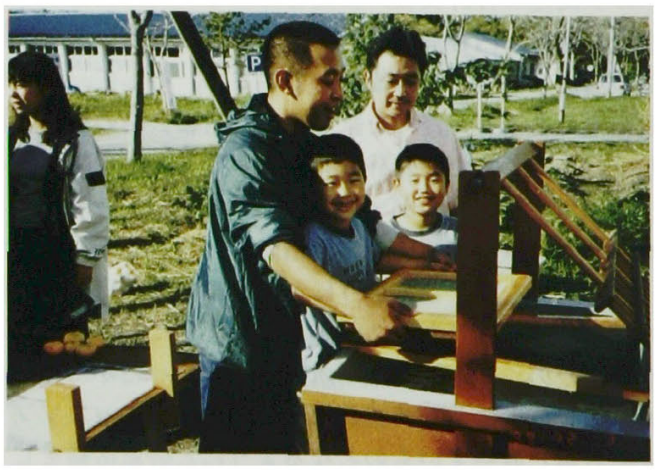

写真 1 大学一日公開での土佐和紙の製造体験風景 


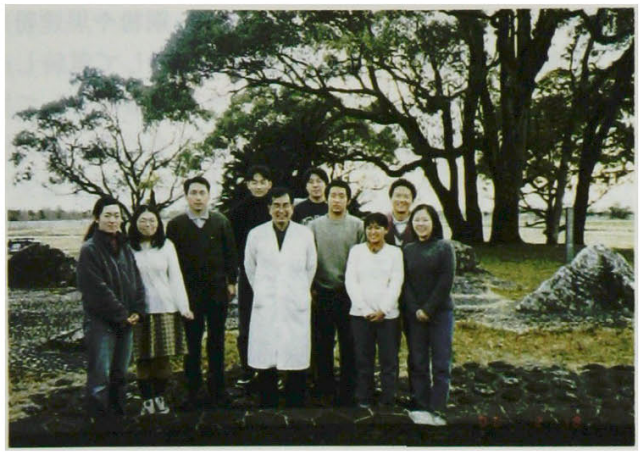

写真 2 研究室メンバー（前列中央：鲛島教授, 左から 3 人目：大谷助教授)

Mokuzai Gakkaishi, 43, 9, 770-777 (1997).

(2) Y. Ohtani. M. Hazama and K. Sameshima : Crucial Chemical Factors for Termiticidal Activity of $\mathrm{Hi}$ noki Wood (Chamaecyparis obtusa) III. Contribution of $a$-terpinyl acetate to the termiticidal activity of hinoki wood. Mokuzai Gakkaishi, 43, 12, 1022-1029 (1997).

(3) Z. Cheng, Y. Ohtani, K. Sameshima, and Z. Mei : Selection of plant population of Kenaf (Hibiscus cannabinus L.) as a papermaking raw material from plant populations on arid hillside land in China. J. Wood Sci. , 44, 296-302 (1998).

(4) B.B. Mazumder, Y. Ohtani and K. Sameshima : Normal Pressure Pulping of Jute, Kenaf and Mesta Bast Fibers. Sen'i Gakkaishi, 54, 12, 654-660 (1998).

(5) S. Premjet. A. Shimamoto, Y. Ohtani, and K. Sameshima : The Importance of TCA Cycle Related Acids in Bacterial Cellulose Production. Sen'i Gakkaishi, 55, 1,7-12 (1999).

\section{卒業生の就職状況}

卒業生は紙パルプ, 紻維加工, 住宅建材, 緑化産業など の企業や地方・国家公務員として多分野で活躍しています。 学部・大学院の入試および教育内容

学部学生は森林科学科に入学し, 共通教育科目, 基䃈教 育科目, 専門コア科目, 専門科目の一部を履修した後, 3 年前期に講座に分属され，講座専門を履修します。 4 年か らは卒業論文と講座専門七ミナーを始めます。高知大学の カリキュラムの特街の一つとして, 上記科目以外に基軸科 目として, 大学学, 情報教育, 日本語技法, 総学科目など

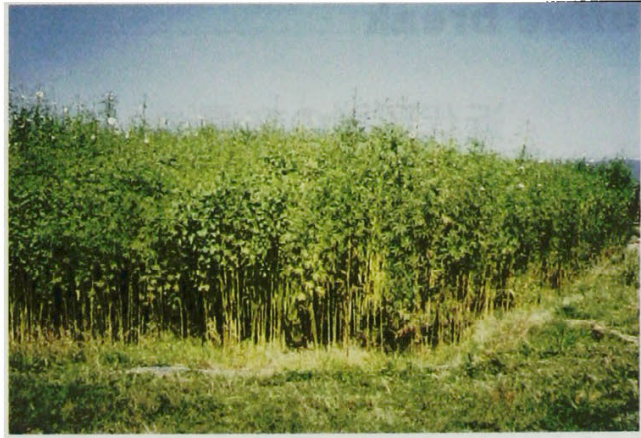

写真 3 研究室のケナフ栽培地（南国市）

の必須科目を課しています。情報教育に関しては入学生全 貝にパソコン携帯を義務付け，4年間を通じた教育を行な っています。

大学院修士課程の入学試験は毎年 9 月上旬と 2 月上旬に 実施されます。その考查は外国語 (英語)，専門科目，口 頭試験からなります。更に, 高知大学農学部は香川大学農 学部とともに爱媛大学農学部を基幹校とした連合大学院博 士課程を持っています。博士課程の入学試験は毎年 10 月 と 2 月の中旬に実施され, その考査は外国語 (英語), 専 門科目，口頭試験からなります。社会人が企業や公的研究 所に籍を置きながら, 博士学位取得への道を開く社会人の 博士課程への入学制度も整っています。

当研究室では他大学・他大学院からの進学を大いに歓迎 しますので，関心のある方はご連絡ください。

企業・他機関との共同研究

平成 9 年 9 月に高知県ケナフ研究会（事務局：当研究室 内）を設立し, 年 3 回程度の研究会を開催すると共に, ケ ナフの利用に関して企業, 試験場などと共同研究を行なっ ています。シロアリ防除に関しては企業との共同研究およ び受託研究を行なっています。

連絡先

于783-8502 高知県南国市物部乙 200

高知大学農学部森林科学科

森林資源利用学講座木材化学研究室

鮫島一彦 Tel\&Fax. 088-864-5142；Fax. 088-864-5200 E-mail samesima@fs.kochi-u.ac.jp

大谷慶人 Tel\&Fax. 088-864-5143; Fax. 088-864-5200 E-mail ohtani@fs.kochi-u.ac.jp 
ここでは，今後の板紙抄紙機はすでに証明された機器の組合せで䡔成できることをしめしており，そ の高生産性板紙抄紙機の仕様をまとめると，坪量 $160 \sim 400 \mathrm{~g} / \mathrm{m}^{2}$, ワイヤ幅最大 $10.5 \mathrm{~m}$, 抄速 600 1,000 $\mathrm{m} / \mathrm{min}$, 生産量最大 $3,000 \mathrm{t} /$ 日となる。

(本文 79 ページ)

\title{
セルケム社の二酸化塩素製造プロセス
}

\author{
セルケム株式会社 (スウェーデン) アンダース・ダール
}

セルケムは世界最大の塩素酸ソータメーカーであるエカケミカルスのエンジニヤリンダ会社として長 年にわたり二酸化堭素プロセスの開発を積極的に行ってきている。当社の二酸化塩素プロセスは基本的 には今日世界中で実用化されているすべてのブロセスを網羅している。

本報では日本のパルプ工䀛の要求に最も適していると考えられる SVP-LITEのフロセス及びHP-A ${ }^{\mathrm{TM}}$ プロスをまず取り上げその特長について述べる。SVP-LITEは操莱の信頼性と安全性の面で非常に 優れており，また今日では最も経済的な汎用ブロセスである。SVPプロセスは多くの翼なったモード での逎転に対応できる柔软な技術であり世界で 70 基以上の実績がある。

HP-A ${ }^{\mathrm{TM}}$ プロセス（Hydrogen Peroxide-Atmospheric の略）は従来の常圧システムを新技術に転換す る場合に特に有利である。既存の反応器システムを使って能力を 1.5〜2 倍に增やす事が可能である。

また最近開発した SVP-GLS フロセス（GLSはGenerator Liquor Splitの略）についても简単に述べ る。このブロセスはSVP-LITEのフロセスもしくはSVP-HP プセスに追加の設備をつけたもので, 副 生艺硝を基本的には酸と苛性ソータに転換することができる。

SVP-フロセス及びHP-A TM プセスは国内では保土谷エンジニヤリング碀が販売している。

(本文 83 ページ)

\section{カラーシート検査装置の開発及び導入事例}

オムロン株式会社 ビジョンシステム事莱部技術部 松井 秀人

カラーシート検査装葨はこれまでの検查装圂と大きく概念を替えた。単にモノクロ検查をカラー化し ただけではなく，検出アルゴリスムに，バターンマッチンク方式を採用し，検出久陥種を大幅に改善し た。

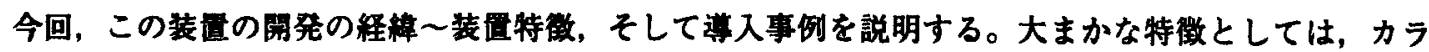
一化による色欠陥検出精度の向上，解易な画像処理による安定した検查，そして，バターンマッチンタ による薄污れ検出精度の大幅な向上が上げられる。また, 判別においては, ライン処理からエリア処理 に代えることで，人の目に近い判別が可能である。

(本文 90 ページ) 


\section{報 文概 要 一 筧 \\ バイオマス変換のためのケナフ成分の分別と利用 \\ 一ケナフ勒皮のアルカリ酸素パルブ化およびケナフ酸素パルプの漂白一}

北海道大学大学院宸学研究科敖日 格勒，佐野嘉拓

ケナフ勒皮パルプを針葉樹クラフトパルプの補填パルプとして利用するために，ケナフ (Hibiscus cannabinis）勒皮のアルカリ酸素パルプ化と得られるパルプの無塩素漂白を検討した。アルカリ酸素パルプ 化はクラフトバルプの酸素漂白の条件に基づき設定した。表皮が褐色化した勒皮は表皮の脱色に多くの アルカリと煩雑な操作が必要であっだ。しかし, 一般的な緑色表皮の勒皮では 8 15\% NaOH（対䩗 皮), $110 \mathrm{C}$ ，酸素圧 $7 \mathrm{~kg} / \mathrm{cm}^{2}, 1$ 時間のパルブ条件により，カッパ価 44〜54のパルプが 67〜 78\% の収率 で得られた。パルブは50〜70\% 酢酸水で造流することにより，パルブ収率は 56〜 59\% (対勒皮)に低 下し, カッバ価は 21〜31 まで低下した。酢酸水で処理した酸素パルブは 5 \% Pa-1\% P-1\% Pa-1\% $\mathrm{Pa}, 5 \% \mathrm{~Pa}-1$ \% Pa-0.2\% D/0.2\% P-1 \% P などのシークエンスにより完全漂白することが可能であっ た。強度試験の結果は䩗皮の酸素パルプおよび漂白パルプが針葉榯クラフトパルプの補填パルプとして 利用できることを示した。

(本文 99 ページ)

\section{塗料の保水性が塗工紙物性に与える効果（第 3 報） 一塗工層表面のラテックス懐度一}

\section{日本製紙株式会社 研究開発本部技術研究所 大籍幸治，森井博一，藤原秀樹}

塗料の塗工原紙に対する保水性は，最終製品である染工紙の品兵を決定する重要な因子のひとつであ ることは良く知られている。洛料の保水性を测定する手段として数多くの保水性測定の提案がなされて いるが，一般的に塗料の保水性という言葉は明確には定義されていない。第一報では，塗料の保水性を

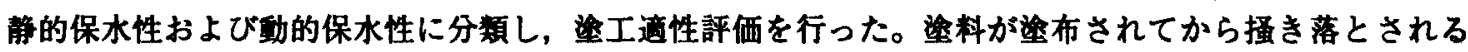
までの間の脱水量は, フレード直下での流動性に大きく影雷を与えている。また，塗料が脱水する祭， 堻料中の水と共にバインター成分も原紙に浸透し，このバインターの浸透挙動が塗工紙物性に大きな影 害を与える因子のひとつになると考えられる。そのため第二報では，料のバインダーの浸透举動を明 確にするために，淘料および，法料中の水およびラテックスから構成される希薄ラテックスの脱水量を 湘定し，その除，水と共にバインター成分（ラテックス）が原紙へ漫透する挙動を，クロマトスキャナ を使用して湘定した。これらの值，ハイシア粘度，脱水量等は，染工適性および塗工紙品質に影謷を与 えると考えられる。

本報告では，1迢料のハイシア粘度，保水性およびドゥェルタイム等に依存するブレード压追従性， および(2)，染料中のバインタ（ラテックス）と塗料中の顔料, 助郕等との相互作用に依存する原紙への

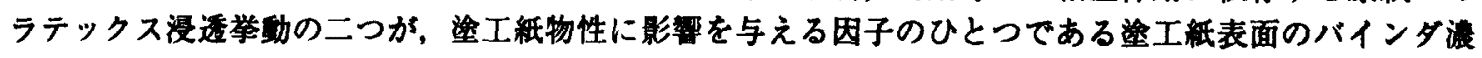
度に与える影籍を検討した。

フレード圧追従性およびラテックスの浸透挙動は，クロマトスキャナを用いて測定した塗工紙表面の パインダ灌度と密接な関係が見出された。塗料粘度, 保水性, ラテックスの浸透挙動等を評価すること により，鋈工紙表面のバインタ浱度の傾向を推定することが可能であると考えられる。

(本文 107 ページ) 